\author{
Maria MRÓWCZYŃSKA ${ }^{1}$ \\ Malgorzata WAWER ${ }^{2}$
}

\title{
PRÓBA BUDOWY KATASTRU SLONECZNEGO NA OBSZARZE MIASTA ZIELONA GÓRA
}

\begin{abstract}
W artykule przedstawiono możliwości wykorzystania danych pozyskanych metodą skaningu laserowego do budowy katastru słonecznego, umożliwiającego dostarczenie szczegółowych informacji na temat przydatności dachów budynków do montażu ogniw fotowoltaicznych. W artykule przybliżono funkcjonowanie wybranych, istniejących w Europie i na świecie, portali geoinformacyjnych zawierających dane dotyczące katastru słonecznego oraz podjęto próbę budowy katastru (mapy nasłonecznienia) dla fragmentu obszaru miasta Zielona Góra. W tym celu został wykorzystany numeryczny model pokrycia terenu zapisany w postaci rastrowej, uzupełniony o dane metrologiczne pozyskane dla omawianego obszaru oraz obrysy przyziemia budynków stanowiące element bazy danych obiektów topograficznych.
\end{abstract}

Słowa kluczowe: mapa nasłonecznienia, numeryczny model pokrycia terenu, portal geoinformacyjny

\section{Wstęp}

Zastosowanie materiałów energetycznych spowodowało, że w ciągu ostatnich 50 lat na świecie podwoiła się liczba ludności, unowocześnił przemysł, zwiększyły się możliwości transportowe, rolnictwo zostało tak zmechanizowane, że kraje rozwinięte produkują nadwyżki żywności. Taki szybki rozwój spowodował, że następuje nieustanne zanieczyszczanie naszego środowiska.

Wzrost stężenia $\mathrm{CO}_{2} \mathrm{w}$ atmosferze powoduje powiększenie się dziury ozonowej, emisja tlenku siarki i azotu ze spalania węgla jest przyczyną powstawania kwaśnych deszczy oraz smogu, globalna temperatura rośnie powodując topnienie lodowców i wzrost poziomu mórz i oceanów.

W celu zmniejszenia negatywnych wpływów wykorzystania nieodnawialnych źródeł energii w 1992 roku w Rio de Janeiro została zawiązana Ramowa

\footnotetext{
${ }^{1}$ Autor do korespondencji: Maria Mrówczynska, Uniwersytet Zielonogórski, 65-516 Zielona Góra, ul. Z. Szafrana 2, m.mrowczynska@ib.uz.zgora.pl

2 Małgorzata Wawer, 85-863 Bydgoszcz, ul. Bohaterów Kragujewca 2/16, Gosia.wawer@gmail.com
} 
Konwencja Narodów Zjednoczonych w Sprawie Zmian Klimatu (ang. United Nations Framework Convention on Climate Change), a w 1997 roku podpisano protokół z Kioto, którego głównym celem jest ograniczenie emisji gazów cieplarnianych.

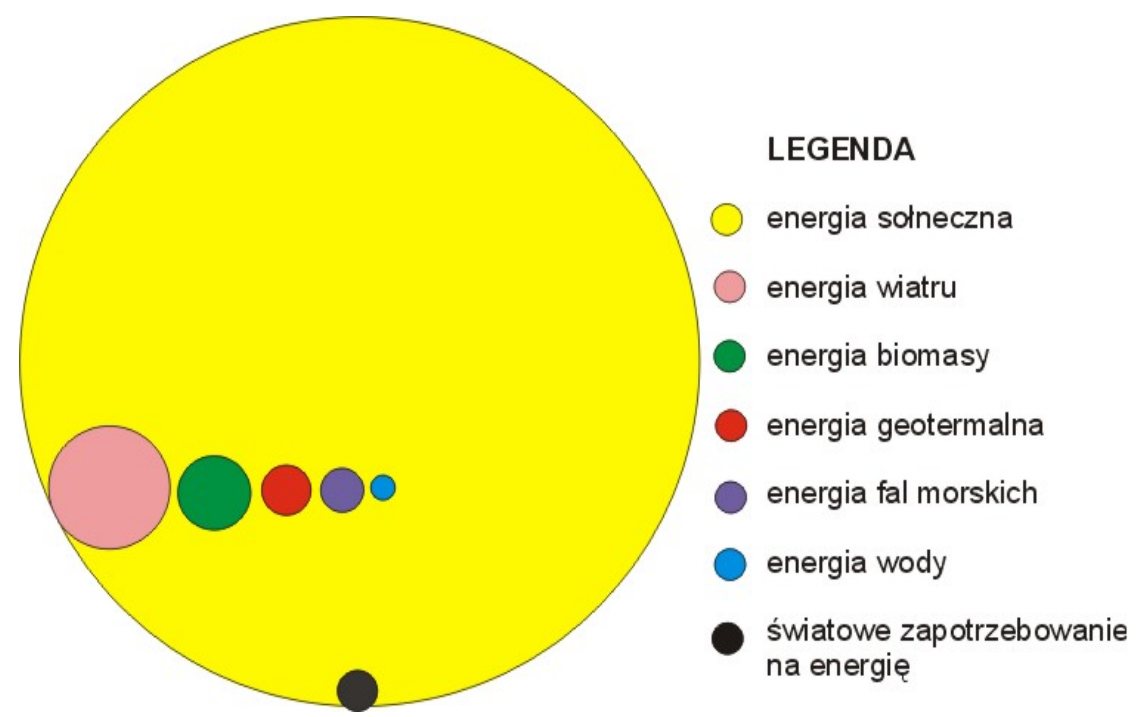

Rys. 1. Wielkość energii z OZE na świecie na podstawie [5]

Fig. 1. Amount of energy from renewable energy sources (RES) in the world according to [5]

Najbardziej korzystnym rozwiązaniem problemu zanieczyszczenia środowiska i ograniczenia emisji gazów cieplarnianych jest wykorzystanie odnawialnego źródła energii (OZE) takich jak: energia słoneczna, wiatrowa, wodna, energia geotermalna, energia fal i pływów morskich oraz biomasa. Na rysunku 1 przedstawiono wielkość energii możliwej do pozyskania z OZE, w porównaniu do ogólnego światowego zapotrzebowani na energię [5]. Jak widać, energia z odnawialnych źródeł jest w stanie zaspokoić światowe zapotrzebowanie, a Słońce może dostarczyć najwięcej tego rodzaju energii. W tym kontekście celowym jest tworzenie portali geoinformacyjnych zawierających dane pozwalające na podjęcie prawidłowych decyzji dotyczących lokalizacji i montażu kolektorów słonecznych wykorzystywanych m.in. do podgrzania wody lub montażu ogniw fotowoltaicznych w celu produkcji energii elektrycznej [Chwieduk 2008]. Określenie potencjału energii promieniowania słonecznego (tworzenie katastru słonecznego, map nasłonecznienia) bazuje głównie na numerycznym modelu pokrycia terenu (NMPT) pozyskanym z lotniczego skaningu laserowego i zapisanym w formacie rastrowym. W artykule zostanie przedstawiona możliwość wykorzystania NMPT do opracowania katastru słonecznego dla fragmentu obszaru miasta Zielonej Góry. 


\section{Energia promieniowania słonecznego}

Promieniowanie słoneczne w postaci promieniowania elektromagnetycznego docierające do powierzchni Ziemi w najbardziej sprzyjających warunkach (pomiędzy $23^{\circ}$ szerokości geograficznej południowej i $23^{\circ}$ szerokości geograficznej północnej oraz przy bezchmurnym niebie) posiada natężenie około $1100 \mathrm{~W} / \mathrm{m}^{2}$. W Polsce średnia wartość nasłonecznienia, definiowanego jako wielkość opisująca zasoby energii słonecznej $\mathrm{w}$ danym miejscu i czasie wyrażana $\mathrm{w} \mathrm{kWh} / \mathrm{m}^{2}$ na dzień, miesiąc lub rok, waha się w zakresie od 900 do $1100 \mathrm{kWh} / \mathrm{m}^{2}$ rocznie [2]. Największe wartości nasłonecznienia są rejestrowane w okolicach Tatr, zaś najmniejsze wartości sumy promieniowania słonecznego występują w północnej części województwa mazowieckiego (rys. 2.)

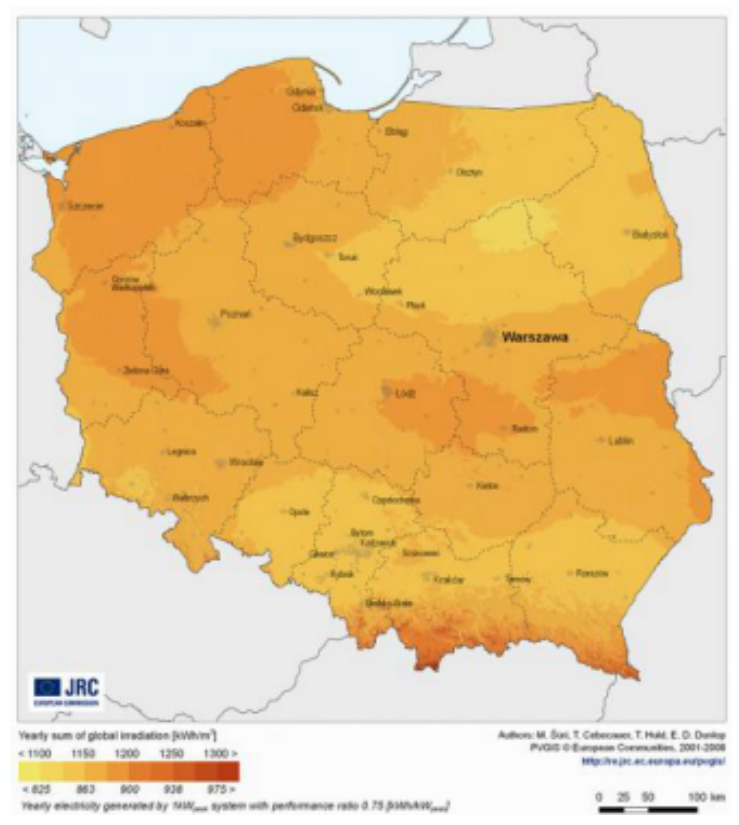

Rys. 2. Rozkład nasłonecznienia na obszarze Polski [7]

Fig. 2. Insolation distribution in Poland [7]

Przy instalowaniu kolektorów oraz ogniw fotowoltaicznych, bardzo ważnym zagadnieniem jest określenie kąta padania promieni słonecznych. Kąt padania promieni jest bowiem odpowiedzialny za wartość natężenia promieniowania jaka jest odbierana przez kolektor. Przykładowo, gdy Słońce jest w zenicie wartość natężenia promieniowania jest równa $1100 \mathrm{~W} / \mathrm{m}^{2}$, jeżeli natomiast kąt padania wynosi $45^{\circ}$ wówczas wartość natężenia maleje do $769 \mathrm{~W} / \mathrm{m}^{2}$ [6]. Graficzna ilustracja zależności natężenia promieniowania od kąta podania promieni słonecznych została przedstawiona na rysunku 3. 


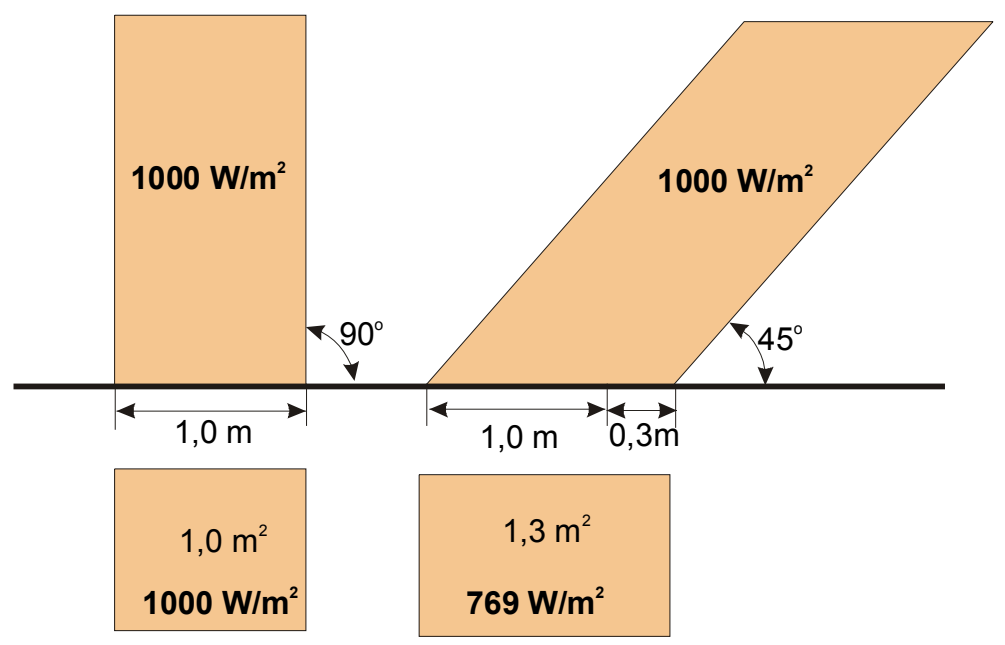

Rys. 3. Natężenie promieniowania w zależności od kąta padania promieni słonecznych [7]

Fig. 3. Sunlight intensity depending on the angle of sun rays [7]

Najbardziej korzystny kąt odchylenia kolektorów słonecznych od poziomu na obszarze Polski waha się od $20^{\circ}$ dla instalacji podgrzewającej wodę w przydomowych basenach do $90^{\circ}$ dla instalacji podgrzewającej wodę użytkową dla całorocznych potrzeb gospodarstwa domowego [6]. Przy montażu kolektorów oraz ogniw fotowoltaicznych należy również wziąć pod uwagę lokalizacje obiektu względem stron świata, a także istniejące przeszkody terenowe, które przyczyniają się do rozproszenia promieniowania. Natomiast przy określaniu wartości natężenia promieniowania słonecznego musimy uwzględnić również dane meteorologiczne, co nie jest łatwe, ponieważ powinniśmy bazować na wieloletnich zapisach informacji dotyczących promieniowania słonecznego, zachmurzenia oraz zamglenia [3]. Stworzenie ogólnodostępnego portalu geoinformacyjnego pozwala każdemu potencjalnemu użytkownikowi na sprawdzenie czy opłacalna jest inwestycja $\mathrm{w}$ instalację solarną na dachu interesującego go budynku, bez konieczności przeprowadzania przez niego żmudnych obliczeń.

\section{Przyklady katastrów słonecznych}

Teoretycznie stworzenie słonecznego katastru nie jest zadaniem szczególnie skomplikowanym, mając bowiem w dyspozycji numeryczny model pokrycia terenu oraz dane klimatyczne obliczamy potencjał słoneczny możliwy do uzyskania na konkretnym budynku. Uzyskane w ten sposób wyniki umieszczamy na serwerze i udostępniamy w internecie w wybranej technologii Web GIS. W praktyce jednak jest to o wiele bardziej skomplikowane. Najprostsze słoneczne geoportale wykorzystują niskorozdzielcze dane klimatyczne oraz 
numeryczny model terenu. Przykładem takiego geoportalu jest portal PVGIS stworzony dla Europy i Afryki, a od września 2014 również dla Azji (rys. 4). Użytkownik tego serwisu musi nie tylko podać przybliżoną lokalizację interesującego go budynku, ale również spadek i ekspozycję dachu oraz typ ogniw fotowoltaicznych. W wyniku otrzymuje przybliżoną informację o ilości energii możliwej do pozyskana na obszarze dachu, niestety w jednostkach, które czytelne są tylko dla fachowców.

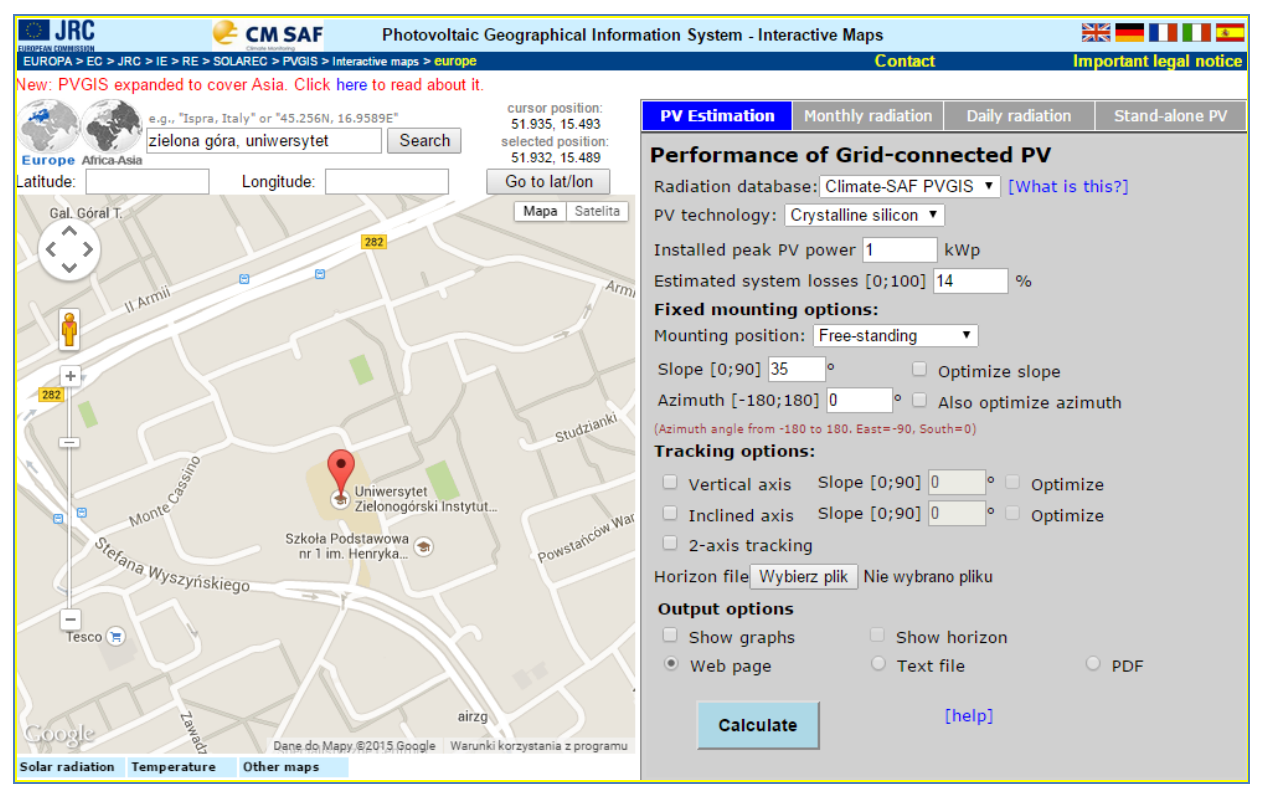

Rys. 4. Portal geoinformacyjny PVGIS [9]

Fig. 4. Photovoltaic Geographical Information System (PVGIS) portal [9]

Chcąc uzyskać bardziej szczegółowe i praktyczne informacje musimy wykorzystać wysokiej rozdzielczości dane pozyskane metodą skaningu laserowego. Przykładem takiego katastru o szczegółowości CityGML LoD1 (niska klasa dokładności, tylko płaskie dachy) jest kataster stworzony dla regionu Centralny Szwarcwald w Niemczech. W tym serwisie uwzględnione są czynniki lokalizacyjne takie jak: nachylenie, zacienienie, globalne promieniowanie przyjęte jako średnia z 20 lat (rys. 5).

Większość istniejących geoportali słonecznych uwzględnia kształt dachu, dzięki czemu istnieje możliwość określenia, jaka część powierzchni dachu nadaje się do montażu kolektorów lub ogniw fotowoltaicznych. Przykładem takich serwisów o szczegółowości CityGML LoD2 (średnia klasa dokładności, dachy w uproszczonej formie) są te wykonane m.in. dla San Francisco, Berlina (rys. 6) oraz Warszawy (rys.7). W przypadku tego drugiego z wymienionych miast, użytkownik ma do dyspozycji więcej opcji, w tym szczegółowość o po- 
ziom wyższą, gdzie każdy fragment dachu jest określony pod względem korzyści płynących z montażu paneli. Inne przykłady tego najbardziej doprecyzowanego rozwiązania to mapy potencjału solarnego dla Wiednia, Los Angeles oraz zmodernizowany w ostatnim czasie dla miasta Boston (rys. 8).

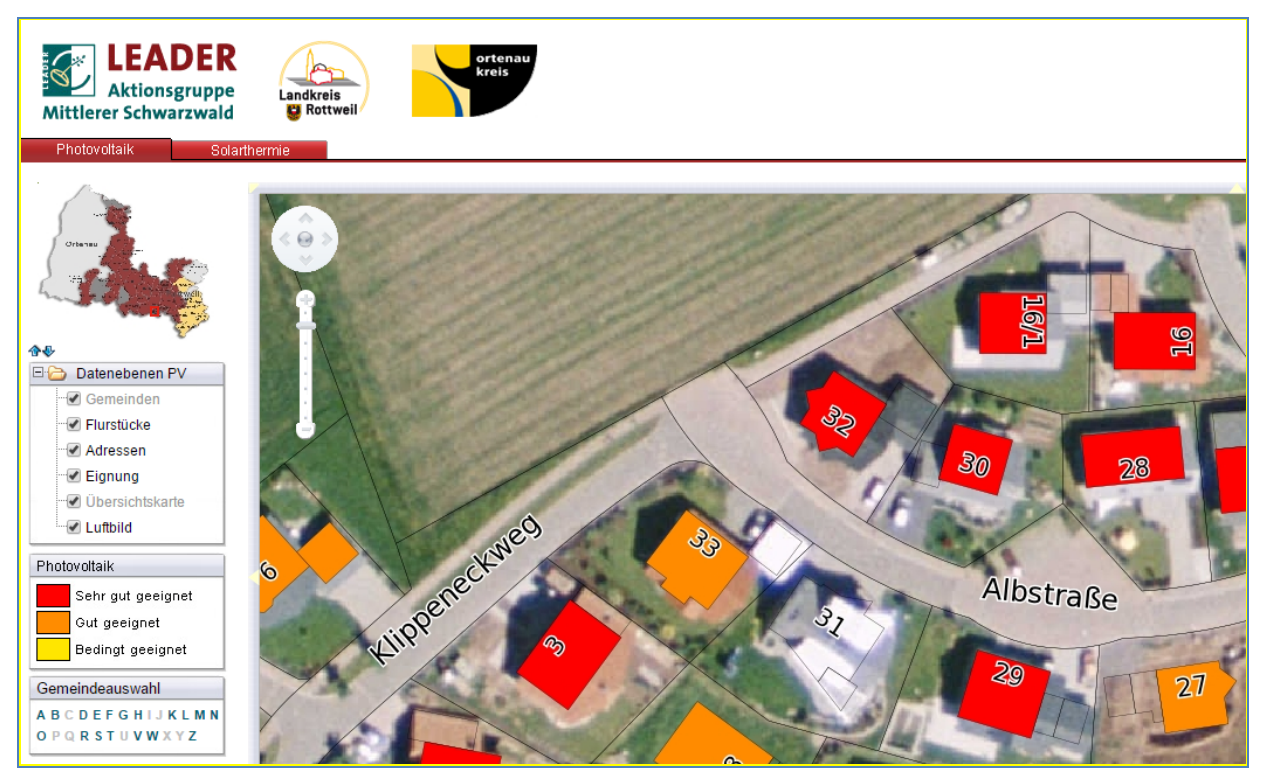

Rys. 5. Słoneczny kataster - Centralny Szwarcwald [10]

Fig. 5. Solar cadastre - Central Schwarzwald [10]

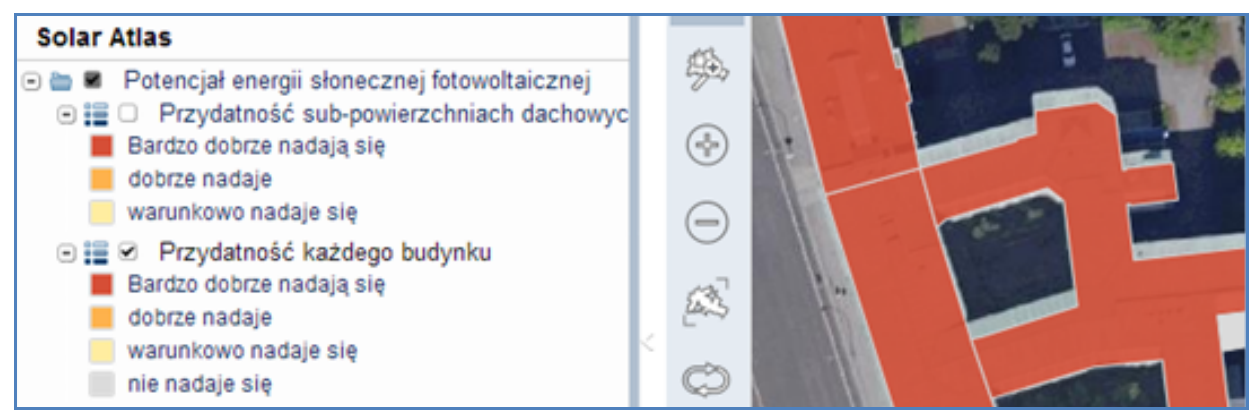

Rys. 6. Słoneczny kataster - Berlin (najkorzystniejszego miejsca pod instalacje solarne) [11]

Fig. 6. Solar cadastre - Berlin (the best locations for solar cell installation) [11] 
O warstwy

† $\square$ 回 Mapa geotermii niskotemperaturowej

4 $\nabla$ Mapa stoneczna

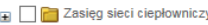

由 $⿴ 囗 十$ Warstwy bazowe

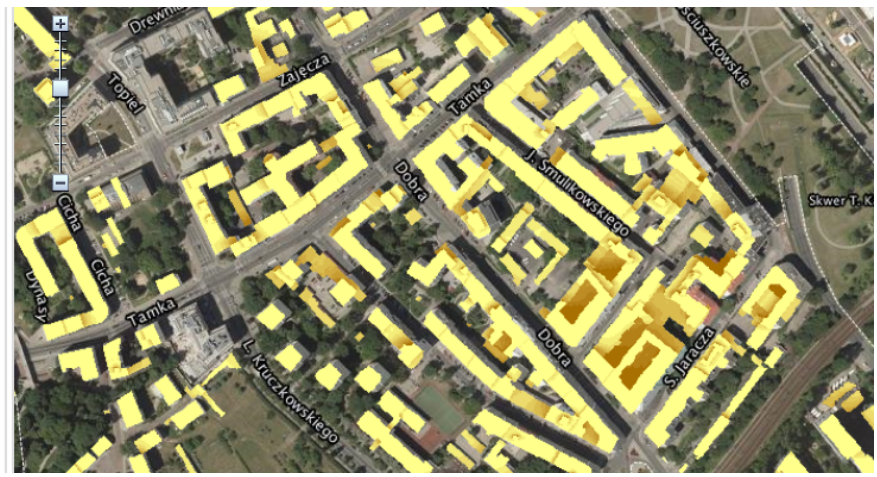

Rys. 7. Słoneczny kataster - Warszawa [12]

Fig. 7. Solar cadastre - Warsaw [12]
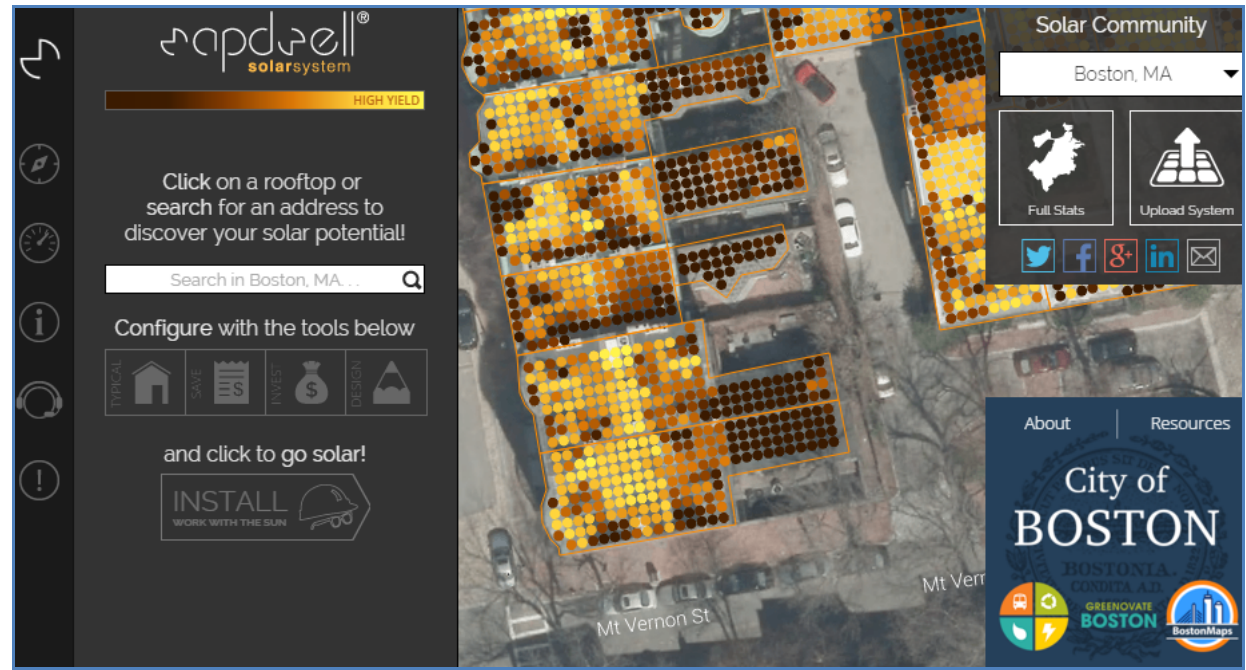

Rys. 8. Słoneczny kataster - Boston [13]

Fig. 8. Solar cadastre - Boston [13]

\section{Słoneczny kataster dla Zielonej Góry}

W prezentowanej pracy podjęto próbę budowy słonecznego katastru dla fragmentu obszaru miasta Zielonej Góry. Do wykonania postawionego zadania zostało wykorzystane oprogramowanie firmy Esri - ArcGIS for Desktop, ArcMap 10.2 [14], ale na rynku programów znajduje się wiele innych, za pomocą których można wykonać postawione zadanie są to m.in. oprogramowanie GRASS GIS oraz SAGA GIS. Do opracowania słonecznego katastru najlepiej wykorzystać numeryczny model pokrycia terenu w formacie ARC/INFO ASCII GRID, w przeciwnym razie plik źródłowy trzeba będzie poddać dodatkowym 
przekształceniom [4]. Do analizy wybranego fragmentu obszaru Zielonej Góry wykorzystano NMPT w skali 1:5000 wykonany metodą skaningu laserowego w ramach projektu ISOK LIDAR. Do analizy wybrano arkusz o godle M-33-8A-a-3-3 (aktualność danych na dzień 12.07.2011 r., charakterystyka przestrzeni $12 \mathrm{p} / \mathrm{m}^{2}$, błąd średni wysokości $0,15 \mathrm{~m}$ ), na którym dominująca część zabudowy to zabudowa jednorodzinna oraz zabudowa mieszana $\mathrm{z}$ wysokimi budynkami Uniwersytetu Zielonogórskiego.

Wykorzystana aplikacja ArcMap [14] wymaga na wstępie podczytania mapy bazowej znajdującej się w pakiecie programu, która będzie służyła jako tło dla wynikowego, skonwertowanego rastra, dla którego należy określić układ współrzędnych. Kolejnym krokiem jest obliczenie promieniowania z powierzchni rastra (narzędzie Area Solar Radiation) oraz weryfikacja uzyskanych danych. Po wykonaniu tych czynności otrzymujemy cztery wyniki w postaci rastrowej przedstawione na rysunku 9 w sposób następujący: a) promieniowanie bezpośrednie; b) promieniowanie rozproszone, c) czas promieniowania dochodzącego do powierzchni Ziemi, d) promieniowanie globalne.

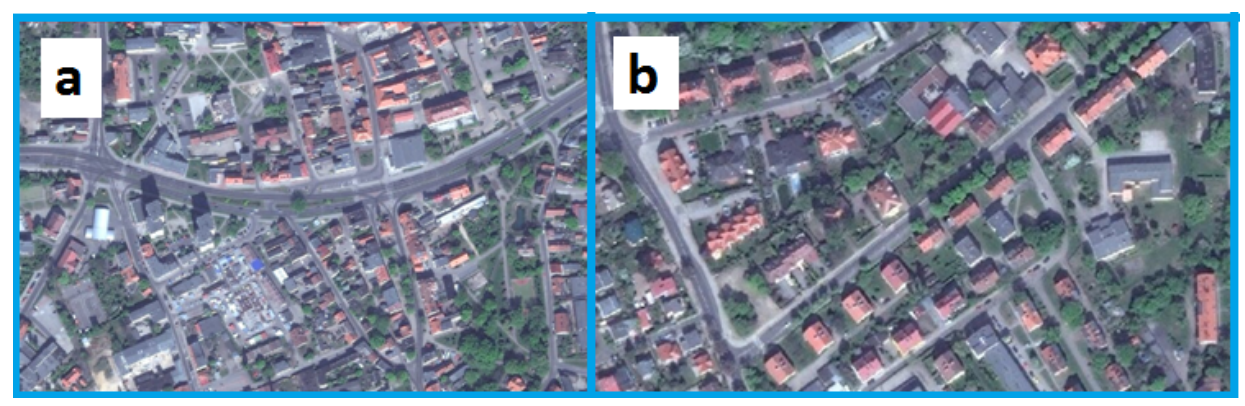

Rys. 9. Obszar opracowania, gdzie: a) zabudowa mieszana, b) zabudowa jednorodzinna [14]

Fig. 9. Area under analysis, where: a) different types of buildings, b) detached houses [14]

Do końcowej analizy wybrano rastry $\mathrm{z}$ promieniowaniem globalnym (rys. 9d), sklasyfikowane na 3 grupy: promieniowanie niekorzystne $<900 \mathrm{kWh} / \mathrm{m}^{2}$, promieniowanie dobre $900-1100 \mathrm{kWh} / \mathrm{m}^{2}$, promieniowanie bardzo dobre $>1100 \mathrm{kWh} / \mathrm{m}^{2}$. Zarówno obszar z zabudową jednorodzinną jak i obszar z zabudową mieszaną zostały opracowane dla pory letniej (czerwiec 2014) oraz pory zimowej (grudzień 2014). Uzyskane wyniki zostały porównane $\mathrm{z}$ danymi opublikowanymi przez Ministerstwo Infrastruktury i Rozwoju (tabela 1) prezentującymi statystyczne dane klimatyczne dla obszaru Zielonej Góry do obliczeń możliwości energetycznych budynków (ITH - suma całkowitego natężenia promieniowania na powierzchnię poziomą $\left.\mathrm{Wh} / \mathrm{m}^{2}\right)$. 


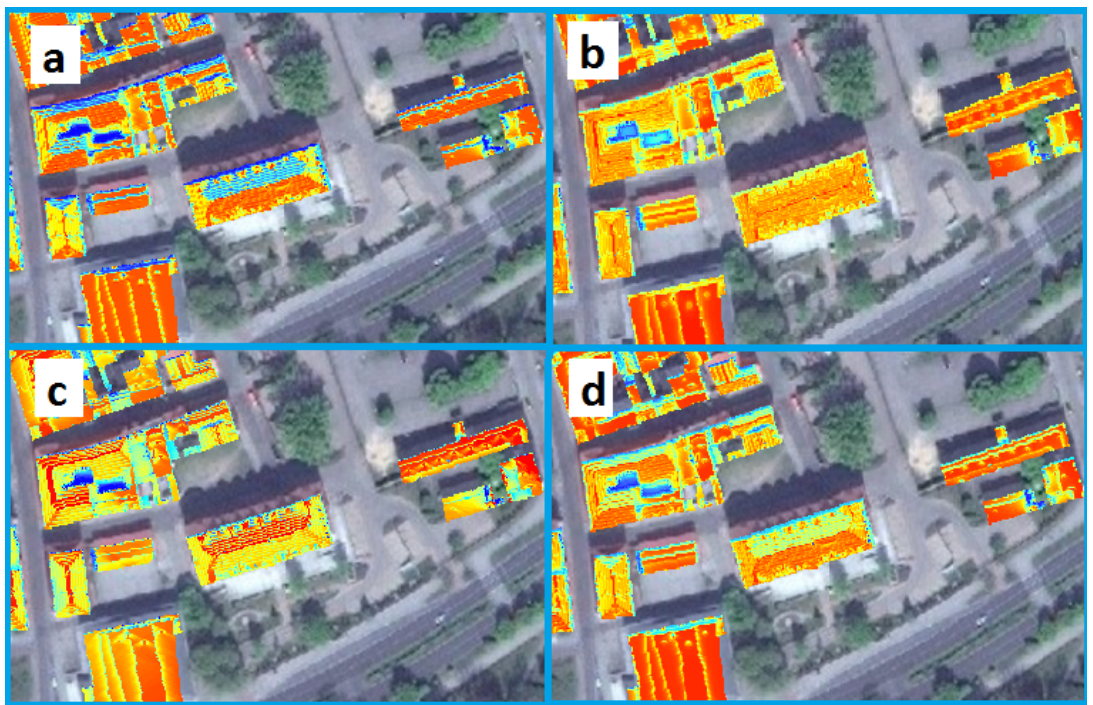

Rys. 10. Rastry wynikowe po zastosowaniu narzędzia Area Solar Radiation [14]

Fig. 10. Resultant raster graphics after the application of the Area Solar Radiation tool [14]

Tabela 1. Suma całkowitego natężenia promieniowania ITH na powierzchnię poziomą [15]

Table 1. Sum of the total ITH sun ray intensity reaching a flat surface [15]

\begin{tabular}{|c|c|c|c|c|c|c|}
\hline \multirow{4}{*}{ 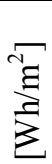 } & \multicolumn{6}{|c|}{ Miesiące } \\
\hline & I & II & III & IV & $\mathrm{V}$ & VI \\
\hline & 21991 & 31525 & 61971 & 99228 & 124117 & 132708 \\
\hline & \multicolumn{6}{|c|}{ Miesiące } \\
\hline I & VII & VIII & IX & $\mathrm{X}$ & XI & XII \\
\hline E & 127934 & 113023 & 74997 & 47525 & 23794 & 19391 \\
\hline
\end{tabular}

Produkt finalny w postaci katastru słonecznego dla obszaru o zabudowie jednorodzinnej oraz obszaru o zabudowie mieszanej w rozbiciu na czerwiec i grudzień 2014 r. został przedstawiony na rysunkach 10,11 do 14. Tak wykonany kataster słoneczny pozwala użytkownikowi łatwo ocenić, dzięki oznaczeniu potencjału solarnego w trzech kolorach (w przypadku czerwca: biały - niekorzystna, żółty - dobra, czerwony - bardzo dobra), czy montaż instalacji solarnej na analizowanym dachu będzie korzystny. Największą wydajność ogniw fotowoltaicznych uzyskujemy w miesiącach od maja do sierpnia $\left(>110000 \mathrm{Wh} / \mathrm{m}^{2}\right)$, nieco gorszą w kwietniu (90000-110000 Wh/m²)' natomiast pozostałe miesiące mają niezadowalający potencjał. Biorąc pod uwagę ewentualnych użytkowników katastru słonecznego i doświadczenia krajów gdzie taki kataster funkcjonuje, najlepszym rozwiązaniem jest umieszczenie gotowej mapy solarnej na oficjalnej stronie internetowej miasta. Geoportal powinien wówczas posiadać dodatkowo opcje ułatwiające dostęp i ob- 
sługę przez potencjalnego użytkownika jak na przykład możliwość wyznaczenia potencjału solarnego na dachu wybranego budynku.

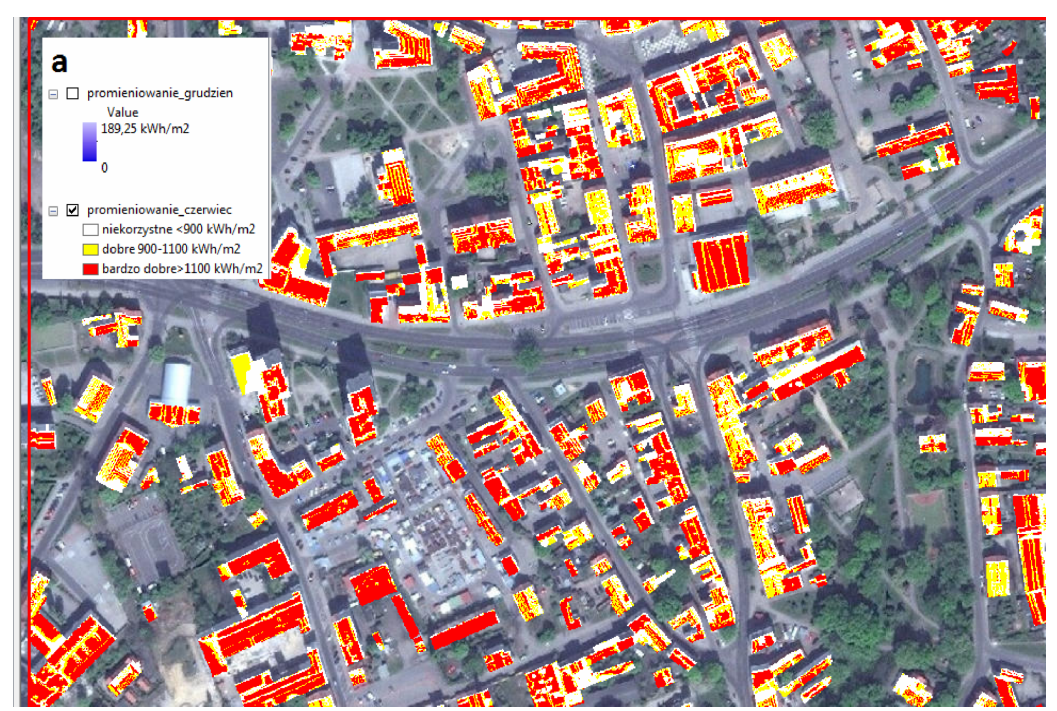

Rys. 11. Mapa potencjału solarnego dla fragmentu Zielonej Góry - zabudowa mieszana a) analiza dla czerwca 2014 r. [14]

Fig. 11. Map of the solar potential for a part of Zielona Góra - different types of buildings: a) analysis for June 2014 [14]

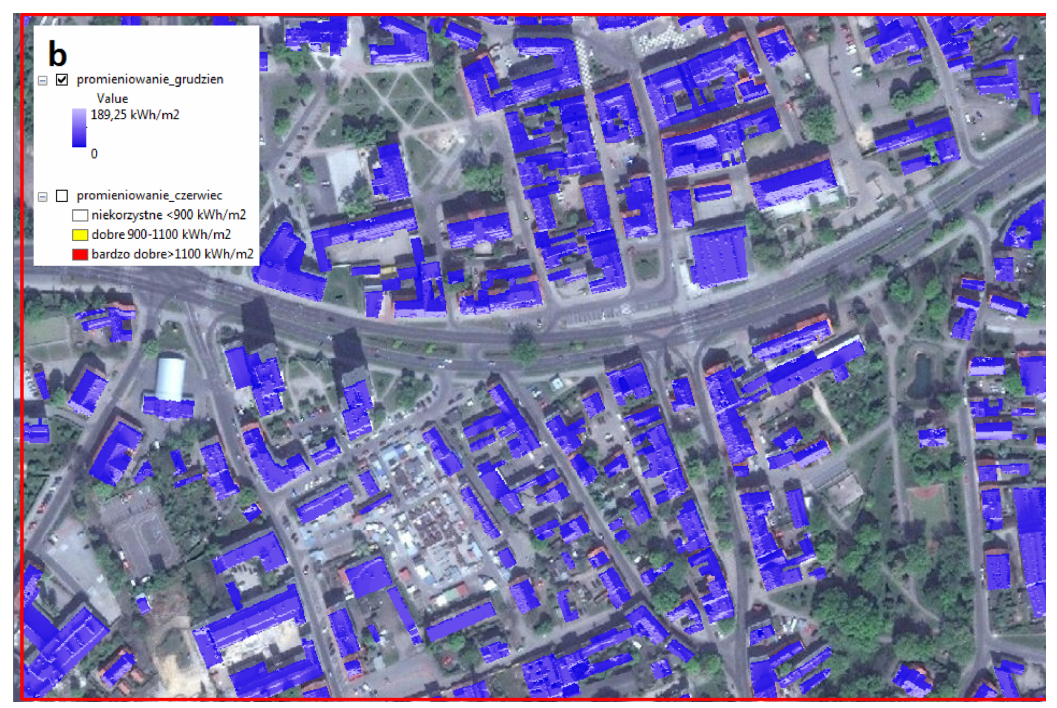

Rys. 12. Mapa potencjału solarnego dla fragmentu Zielonej Góry - zabudowa mieszana: b) analiza dla grudnia 2014 r. [14]

Fig. 12. Map of the solar potential for a part of Zielona Góra - different types of buildings: b) analysis for December 2014 [14] 


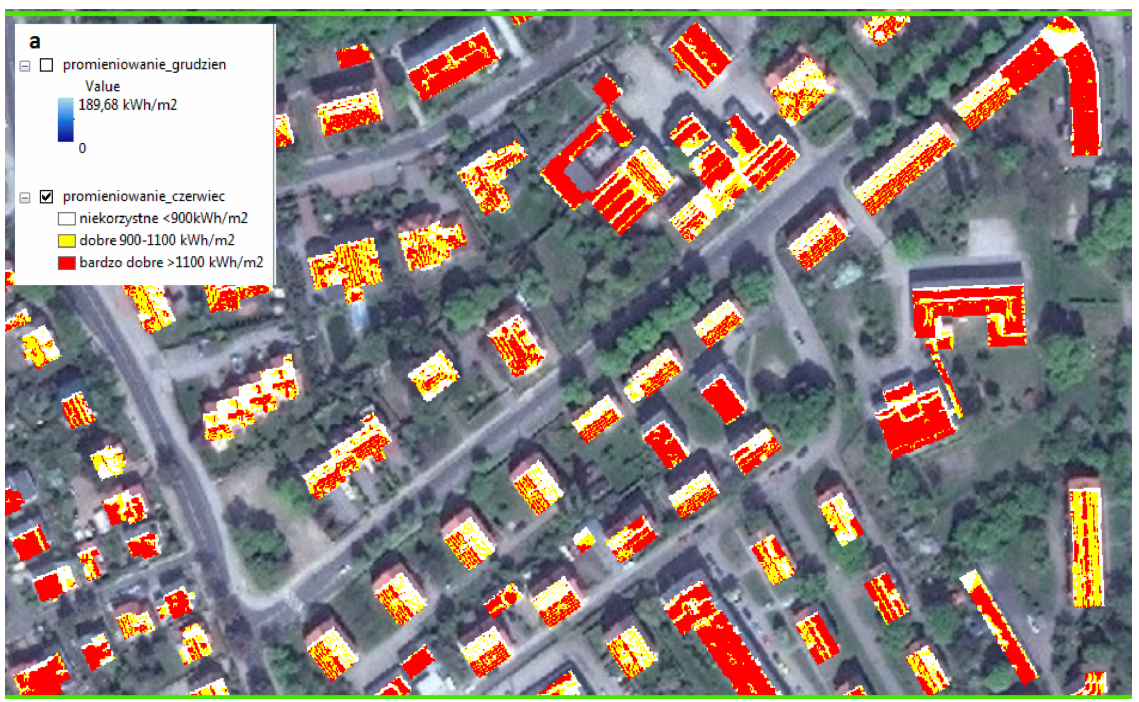

Rys. 13. Mapa potencjału solarnego dla fragmentu Zielonej Góry - zabudowa jednorodzinna: a) analiza dla czerwca 2014 r. [14]

Fig. 13. Map of the solar potential for a part of Zielona Góra - detached houses: a) analysis for June 2014 [14]

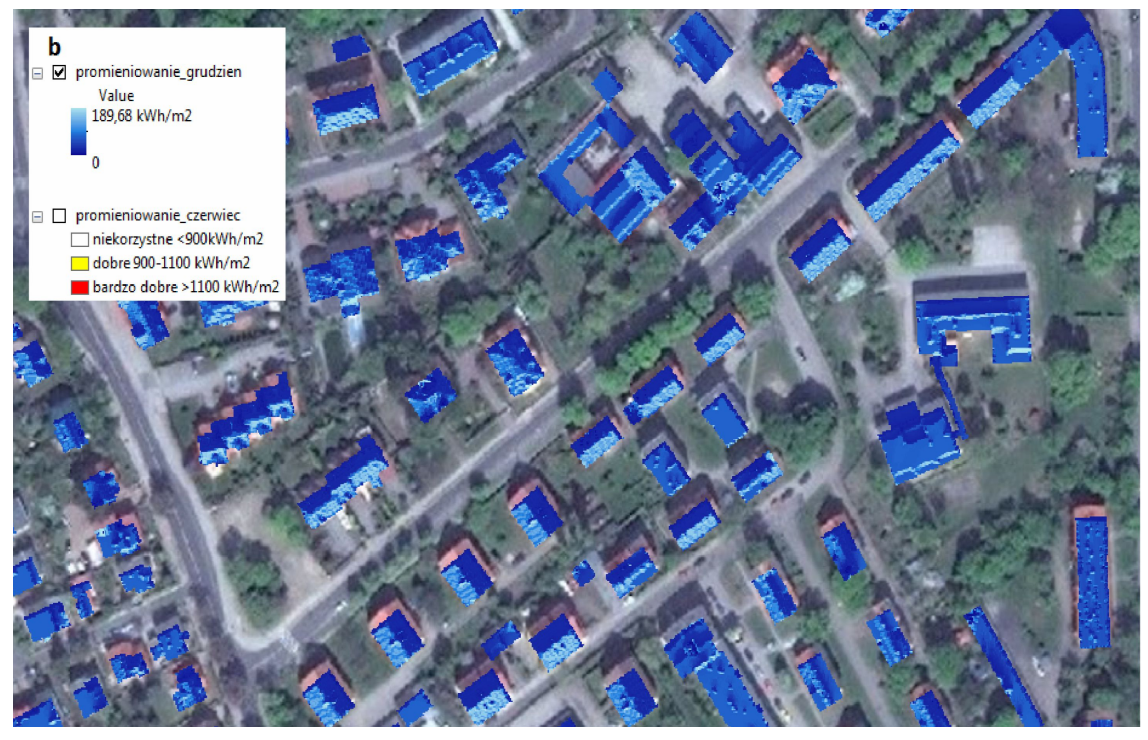

Rys. 14. Mapa potencjału solarnego dla fragmentu Zielonej Góry - zabudowa jednorodzinna: b) analiza dla grudnia 2014 r. [14]

Fig. 14. Map of the solar potential for a part of Zielona Góra - detached houses: b) analysis for December 2014 [14] 


\section{Podsumowanie}

Zastosowanie analiz nasłonecznienia w celu wykorzystania odnawialnych źródeł energii w gospodarce, podnosi świadomość społeczną dotyczącą konieczności tworzenia nowych rozwiązań i ich zastosowania w praktyce. Kataster słoneczny zbudowany na bazie numerycznego modelu pokrycia terenu oraz bazy danych obiektów topograficznych umożliwia pozyskanie przez użytkowników informacji na temat lepszego rozmieszczenia kolektorów i ogniw fotowoltaicznych na dachach budynków oraz pozwala na dokładniejsze prognozowanie ich wydajności. Wiele miast, zarówno na świecie jak i w Unii Europejskiej posiada już katastry słoneczne, a ich doświadczenia mogą i powinny posłużyć do budowy tego typu portali geoinformacyjnych również na obszarze naszego kraju. Warto podkreślić, że informacje pozyskane z geoportali słonecznych są dodatkowym atutem przy ocenie projektów i wniosków o specjalne dotacje proekologiczne na zakup i montaż ogniw fotowoltaicznych i paneli słonecznych.

\section{Literatura}

[1] Chwieduk D.: Dostępność promieniowania słonecznego do obudowy budynku zlokalizowanego w Polsce Centralnej, Polska Energetyka Słoneczna, nr 1-4/2008.

[2] Nowicki M.: Nadchodzi era Słońca, Wydawnictwo PWN SA, Warszawa 2012.

[3] Królikowski J.: Słoneczny kataster, Geodeta nr 1/2011, s. 9-12, Warszawa 2011.

[4] Praca zbiorowa: Podręcznik dla uczestników szkoleń z wykorzystaniem produktów LIDAR, Główny Urząd Geodezji i Kartografii, Warszawa 2014.

[5] Tytko R.: Urządzenia i systemy energetyki odnawialnej, Wydawnictwo i Drukarnia Towarzystwa Słowaków w Polsce, Kraków 2014.

[6] Oszczak W.: Kolektory słoneczne i fotoogniwa w Twoim domu, Wydawnictwo Komunikacji i Łączności, Warszawa 2012.

[7] Wawer M.: Słoneczny kataster, czyli mapa potencjału solarnego dla fragmentu miasta Bydgoszczy, Praca inżynierska, Kujawsko - Pomorska Szkoła Wyższa w Bydgoszczy, Bydgoszcz, 2014.

[8] www.gramwzielone.pl, dostęp: 18 marca $2015 \mathrm{r}$.

[9] www.re.jrc.ec.europa.eu/pvgis, dostęp: 18 marca 2015 r.

[10] www.gpm-kom8.de, dostęp: 18 marca 2015 r.

[11] www.businesslocationcenter.de, dostęp: 18 marca $2015 \mathrm{r}$.

[12] www.mapa.um.warszawa.pl, dostęp: 2 grudnia 2015 r.

[13] www.mapdwell.com/en/boston, dostęp: 18 marca 2015 r.

[14] oprogramowanie firmy Esri - ArcGIS for Desktop, ArcMap ver. 10.2.2

[15] www.mir.gov.pl, 18 marca 2015 r. 


\section{ATTEMPT TO PREPARE A SOLAR CADASTRE FOR THE TOWN OF ZIELONA GÓRA}

\section{S u m m a r y}

The article presents possibilities of using data obtained by aerial laser scanning to make a portal containing detailed geographical information about building roofs on which photovoltaic cells could be installed. The article explains how selected geoportals containing data about solar cadastres work in Europe and in the other parts of the world. It also presents an attempt to prepare a solar cadastre (an insolation map) for a part of the town of Zielona Góra. For this purpose a numerical land cover model was used, presented in raster graphics, complemented with meteorological data obtained for the area under analysis as well as outlines of the ground levels of buildings as a component of the database of topographical objects.

Keywords: insolation map, numerical land cover model, geographical information portal.

Przestano do redakcji:30.05.2015

Przyjęto do druku:10.01.2016

DOI: $10.7862 / \mathrm{rb} .2015 .198$ 